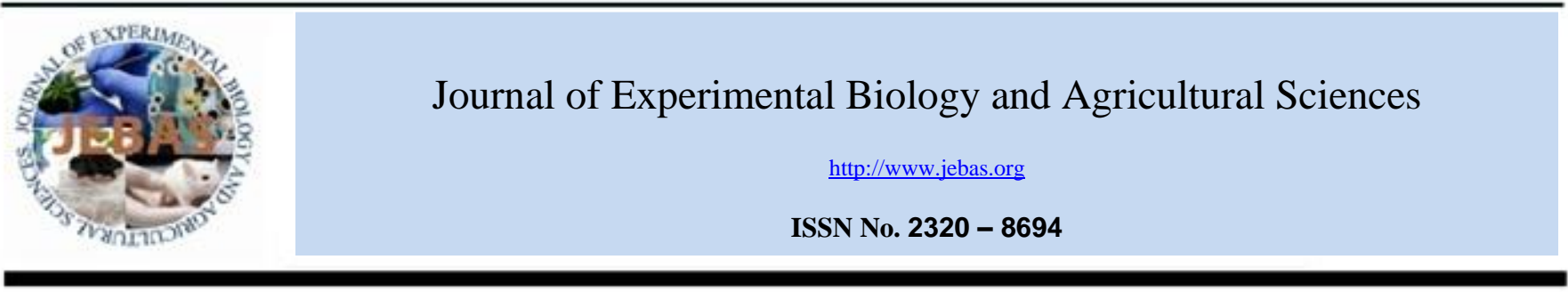

\title{
EVALUATION OF MAIZE HYBRIDS TO TERMINAL DROUGHT STRESS TOLERANCE BY DEFINING DROUGHT INDICES
}

\section{Celaleddin Barutcular ${ }^{1}$, Ayman EL Sabagh ${ }^{2, *}$, Omer Konuskan ${ }^{3}$, Hirofumi Saneoka ${ }^{4}$ and Khair Mohammad Yoldash ${ }^{1}$}

\author{
${ }^{1}$ Department of Field Crops, Faculty of Agriculture, Cukurova University, Adana,Turkey \\ ${ }^{2}$ Department of Agronomy, Faculty of Agriculture, Kafrelsheikh University, Egypt \\ ${ }^{3}$ Department of Field Crops, Faculty of Agriculture, Mustafa Kemal University, Turkey \\ ${ }^{4}$ Plants Nutritional Physiology, Graduate School of Biosphere Science, Hiroshima University, Japan
}

Received - October 14, 2016; Revision - November 06, 2016; Accepted - November 10, 2016

Available Online - November 13, 2016

DOI: http://dx.doi.org/10.18006/2016.4(Issue6).610.616

KEYWORDS
Grain filling stage
Grain yield
Stress indices
Zea mays

\begin{abstract}
Terminal drought stress is one of the most important environmental stress factors which can cause a significant reduction in maize productivity. Therefore, to identify the best selection indices for drought tolerance in maize under terminal drought conditions, this research was conducted in two field experiments with some maize hybrids in two cropping seasons (2014 and 2015) under two moisture levels (normal irrigation and water deficit-water stress) at grain filling stage. Results of study revealed that, yield and major yield traits of hybrids adversely affected due to terminal drought stress, it also causing a reduction in productivity with compare normal irrigation conditions. Water stress significantly affected on maize hybrids and there were high variation among hybrids, which could be befits for screening the genotypes. The special attention was paid to hybrids 71May69, Aaccel and Calgary were showed less reduction of grain yield under terminal drought stress. Concerning the genotypes with high stress susceptibility index (SSI) and tolerance index (TOL) were considered as high susceptible to drought and only suitable for irrigated conditions. Accordingly, the positive relationship between stress indices, drought resistance index (DRI), geometric mean productivity (GMP), harmonic mean (HM), mean production (MP), stress tolerance index (STI) and Yield index (YI), and grain yield could be used as the best selection indices for identifying the tolerant hybrids under terminal drought stress.
\end{abstract}

* Corresponding author

E-mail: ayman.elsabagh@agr.kfs.edu.eg (Ayman EL Sabagh)

Peer review under responsibility of Journal of Experimental Biology and Agricultural Sciences.

Production and Hosting by Horizon Publisher India [HPI] (http://www.horizonpublisherindia.in/).

All rights reserved.
All the article published by Journal of Experimental Biology and Agricultural Sciences is licensed under a Creative Commons Attribution-NonCommercial 4.0 International License Based on a work at www.jebas.org.

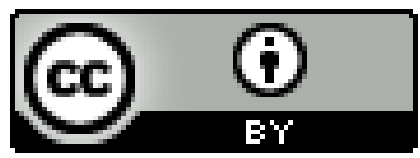




\section{Introduction}

Maize (Zea mays L.) one of the most important summer crops in Turkey and about $18 \%$ of its demand will fulfill by imported (FAO, 2013). Improving of Maize for drought-stress tolerance is one of the most important obstacles as the global need for food, fiber, and fuel increases. Seed companies are succeeding and endorsing drought-tolerant genotypes, but the mechanism of physiological drought-tolerance mechanisms for genotypes are not well understood (Roth et al., 2013).

Environmental stresses adversely affect the growth and productivity of plants (Islam et al., 2011).The performance of crops are highly complex phenomenon under water stress condition and negative affected (Reynolds et al., 2006). Therefore, research on irrigation and water management has concentrated on crop productivity responses to water provide (Chen et al., 2010; Köksal, 2011). It is a fact that when drought stress starts to influence on the plant at reproductive stage, the plant reduces the demand of carbon by reducing the size of sink. As a result, reduction in leaf size, stem extension and root proliferation, flower may drop pollen may die and ovule may abort (Blum, 1996; Farooq et al., 2009). The production of grain yield reduced $60 \%$ due to stress condition at grain filling stages (Khodarahmpour \& Hamidi, 2012). The yield reduction under drought stress was greater at the reproductive stage than at the vegetative and grain filling stages (Fatemi et al., 2006).

Drought stress tolerance development is difficult due to the phenomenon of well-built interactions between genotypes and the environment conditions. Therefore, based on yield loss under water stress conditions with compare to normal conditions, various drought indices were determined that have been used for identification of drought tolerant genotypes (Mitra, 2001), others investigation recorded in a target stress condition (Mohammadi et al., 2011). While others experiments yet have chosen a mid-point and think in selection under both favorable with combined stress conditions (Sio-Se Mardeh et al., 2006). Several selection criteria are suggested to designate genotypes on the basis of their performance in stress and nonstress conditions (Fernandez, 1992).

Genotypes Identification for water stress tolerance at grain filling stage for higher production is very necessary for crop breeding (Menezes et al., 2014). Various previous investigations revealed that, the advantage of these indices for classified genotypes with more stable of productivity under water-limited conditions (Golabadi et al., 2006). Several indices have been recorded as benefits to identify maize to drought stress tolerance (Moradi et al., 2012). The identification of genotypes for drought tolerance is more difficult due to the interactions between genotypes and the environment and there is not having enough knowledge about the role of mechanisms to stress tolerance, therefore, several scientists have used various techniques for assessment role of genetic variations in drought tolerance (Fernandez, 1992).
Thus, by keeping in view the above facts, the present study was undertaken to assess the selection criteria for identifying drought tolerance in maize hybrids and to distinguish high yield maize hybrids which are compatible with stressful and optimal conditions in the Mediterranean condition.

\section{Materials and Methods}

\subsection{Plant material and growing conditions}

The current study was conducted at agricultural experimental area of Cukurova University, Adana, Turkey, during 2014 and 2015 growing season of the second crop. Climatic conditions of this region have been presented in (Table 1). The methodologies have been followed as described previously by EL Sabagh et al. (2015). The design of experiment was randomized complete block design in a strip-split plot manner with four replications. The material of experimental was comprised of 7 hybrids of maize viz. Sancia, Indaco, 71May69, Aaccel, Calgary, 70May82 and 72May80. These hybrids were evaluated at grain filling stage under two moisture levels (normal irrigation and water deficit-water stress), application method and amount of water and time has presented in (Table 1). Each plot was of $10 \mathrm{~m}$ in length and $5.6 \mathrm{~m}$ width including plant stand (Intra row: $70 \mathrm{~cm}$, Inter row: $17 \mathrm{~cm}$ ). Hybrids were sown during first and the second year on 28 June, 2014 and 12 June, 2015, respectively. Regular agronomic practices which are necessary for of the maize crop are carried out. During experiments, nitrogenous fertilizer was utilized within two times of planting, $100 \mathrm{~kg} \mathrm{~N}$ and $\mathrm{P}_{2} \mathrm{O}_{5} \mathrm{ha}^{-1}$ (20-20-0) and V6growth stage $200 \mathrm{~kg} \mathrm{~N} \mathrm{ha}^{-1}$ (Urea).

\subsection{Sampling and measurements of grain yield traits}

At harvesting time, data on various yield components was collected by using standard procedures, the number of plants and ears were counted separately.Yield components plant height $(\mathrm{cm})$, ear height $(\mathrm{cm})$, ear-up stem length $(\mathrm{cm})$, ear diameter $(\mathrm{mm})$, kernel number $\left(\right.$ row $\left.^{-1}\right)$, kernel row $\left(\right.$ ear $\left.^{-1}\right)$, kernel number $\left(\mathrm{m}^{-2}\right)$, grain weight $(\mathrm{mg})$, grain yield $\left(\mathrm{g} \mathrm{m}^{-2}\right)$, biomass $\left(\mathrm{g} \mathrm{m}^{-2}\right)$ and harvest index $(\%)$ were measured.

\subsection{Measurements of indices}

Drought tolerance indices such as, tolerance index (TOL), mean production (MP) were calculated according to the method give by Rosielle \& Hamblin (1981). While the geometric mean productivity (GMP), mean productivity (MP) and stress tolerance index (STI) was measured according to the method given by Fernandez (1992). Further, yield index (YI) and yield stability index (YSI) was calculated as stated by Bouslama \& Schapaugh (1984) and Gavuzzi et al. (1997). Stress susceptibility index (SSI) was measured according to the method give by Fischer \& Maurer (1978) and drought resistance index (DI) was calculated according to Bidinger et al. (1987). 
Table 1 Amount of irrigation and climatic traits during 2014 and 2015 growing season.

\begin{tabular}{|lccccccc|}
\hline Growing period & Max.T. $\left({ }^{\circ} \mathbf{C}\right)$ & Min.T. $\left({ }^{\circ} \mathbf{C}\right)$ & Mean T. $\left({ }^{\circ} \mathbf{C}\right)$ & SR $\left(\mathbf{c a l ~ c m}^{-2}\right)$ & MH $(\boldsymbol{\%})$ & FI $(\mathbf{m m})$ & DI $(\mathbf{m m})$ \\
\hline Sowing-Anthesis & & & $\mathbf{2 0 1 4}$ growing season & & & \\
\hline Anthesis-PM & 33.5 & 25.1 & 28.6 & 535 & 70.1 & 240 & 240.0 \\
\hline Sowing-PM & 32.5 & 22.6 & 27.0 & 428 & 64.9 & 287.4 & 191.4 \\
\hline & 33.1 & 24.1 & 27.9 & 491 & 67.9 & 531.1 & 435.1 \\
\hline Sowing-Anthesis & 32.9 & 23.5 & $\mathbf{2 0 1 5}$ growing season & & & & 313.1 \\
\hline Anthesis-PM & 35.2 & 24.6 & 29.4 & 464 & 63.4 & 476.9 & 308.9 \\
\hline Sowing-PM & 34.1 & 24.1 & 28.5 & 518 & 66.2 & 814.0 & 622.0 \\
\hline
\end{tabular}

(T) temperature; (SR) Solar radiation; (MH) Mean humidity; ( FI) Full irigation: Rain + Irrigation, mm; (DI)Deficit irrigation: Rain + Irrigation, mm.(Source: Meteorological Service of Turkish State)

2.4 Statistical analysis

All data collected for two years average and obtained results were calculated to analyses of variance according to Gomez \& Gomez (1984). Significant means were separated by the Least Significant Difference (LSD) at the 0.05 significance level $(\mathrm{P} \leq 0.05)$.The estimation of correlation for traits was calculated by MSTAT-C computer software package.

\section{Results and Discussion}

3.1 The influence of irrigation regime on yield traits

For yield components, maize hybrids were significantly influenced by irrigation treatments and, water stress lead to a significant reduction in yield traits over control (Table 2). Yield traits such as ear-up stem length, ear height, kernel number per row, grain weight, grain yield, biomass yield and harvest index were adversely affected by water deficit condition except plant height, kernel row ear $^{-1}$ and kernel number $\mathrm{m}^{-2}$. It was found that grain weight was significantly affected by water stress and the highest grain weight $(275 \mathrm{mg})$ was observed under control and the lowest $(253 \mathrm{mg})$ under water stress condition. Low grain weight due to drought stress, as found in present experiments, may indicate that the plants were unable to fully meet the demand of the growing grain. Irrigation regimes effect was the most important source of grain yield during grain growth stage. With respect to grain yield, it was observed that water stress caused significant reduction in grain yield $(-16.36 \%)$ as shown in Table 2.

Table 2 Agronomic traits of maize hybrids under irrigation regime (Two years average).

\begin{tabular}{|c|c|c|c|c|c|c|c|c|c|c|}
\hline & $\begin{array}{l}\text { PH } \\
(\mathbf{c m})\end{array}$ & $\begin{array}{l}\text { E-SL } \\
(\mathrm{cm})\end{array}$ & $\begin{array}{l}\text { EH } \\
(\mathbf{c m})\end{array}$ & $\begin{array}{l}\text { KNR } \\
\left(\text { row }^{-1}\right)\end{array}$ & $\begin{array}{l}\text { KRN } \\
\left(\operatorname{ear}^{-1}\right)\end{array}$ & $\begin{array}{l}\text { KNA } \\
\left(\mathbf{m}^{-2}\right)\end{array}$ & $\begin{array}{l}\text { GW } \\
(\mathbf{m g})\end{array}$ & $\begin{array}{l}\text { HI } \\
(\%)\end{array}$ & $\begin{array}{l}\text { GY } \\
\left(\mathrm{g} \mathrm{m}^{-2}\right)\end{array}$ & $\begin{array}{l}\text { BY } \\
\left(\mathrm{g} \mathrm{m}^{-2}\right)\end{array}$ \\
\hline \multicolumn{11}{|l|}{ Water regimes } \\
\hline Irrigated & 145 & 244 & 100 & 38.2 & 14.9 & 4764 & 275 & 53.2 & 1292 & 2435 \\
\hline Deficit irrigated & 141 & 237 & 96 & 35.3 & 14.9 & 4332 & 253 & 50.5 & 1081 & 2154 \\
\hline$P$ value & $\mathrm{ns}$ & $*$ & $* *$ & $*$ & ns & $\mathrm{ns}$ & $*$ & 0.052 & $* * *$ & $* *$ \\
\hline Drought effect $(\%)$ & -2.97 & -2.86 & -3.59 & -7.47 & 0.11 & -9.07 & -7.96 & -4.99 & -16.36 & -11.53 \\
\hline \multicolumn{11}{|l|}{ Hybrids } \\
\hline H1 & 140 & 224 & 84 & 36.2 & 15.5 & 4825 & 242 & 51.5 & 1149 & 2239 \\
\hline $\mathbf{H 2}$ & 146 & 244 & 98 & 37.2 & 14.6 & 4320 & 283 & 52.0 & 1219 & 2343 \\
\hline $\mathbf{H 3}$ & 151 & 238 & 86 & 34.9 & 16.3 & 4709 & 261 & 53.3 & 1217 & 2294 \\
\hline H4 & 140 & 241 & 101 & 36.5 & 14.2 & 4278 & 281 & 54.8 & 1191 & 2176 \\
\hline H5 & 142 & 241 & 102 & 37.7 & 15.6 & 5084 & 238 & 51.5 & 1199 & 2332 \\
\hline H6 & 145 & 245 & 99 & 39.7 & 13.3 & 4119 & 293 & 49.3 & 1198 & 2448 \\
\hline H7 & 138 & 251 & 113 & 35.1 & 14.5 & 4499 & 255 & 50.7 & 1132 & 2230 \\
\hline Mean & 143 & 240 & 98 & 36.8 & 14.9 & 4548 & 264 & 51.9 & 1187 & 2295 \\
\hline $\mathrm{LSD}_{0.05}$ & 6.0 & 6.2 & 4.9 & 1.52 & 0.41 & 310.9 & 15.4 & 1.83 & 40.1 & 94.6 \\
\hline $\mathrm{CV} \%$ & 4.1 & 2.6 & 5.0 & 4.1 & 2.7 & 6.7 & 5.8 & 3.5 & 3.3 & 4.1 \\
\hline
\end{tabular}




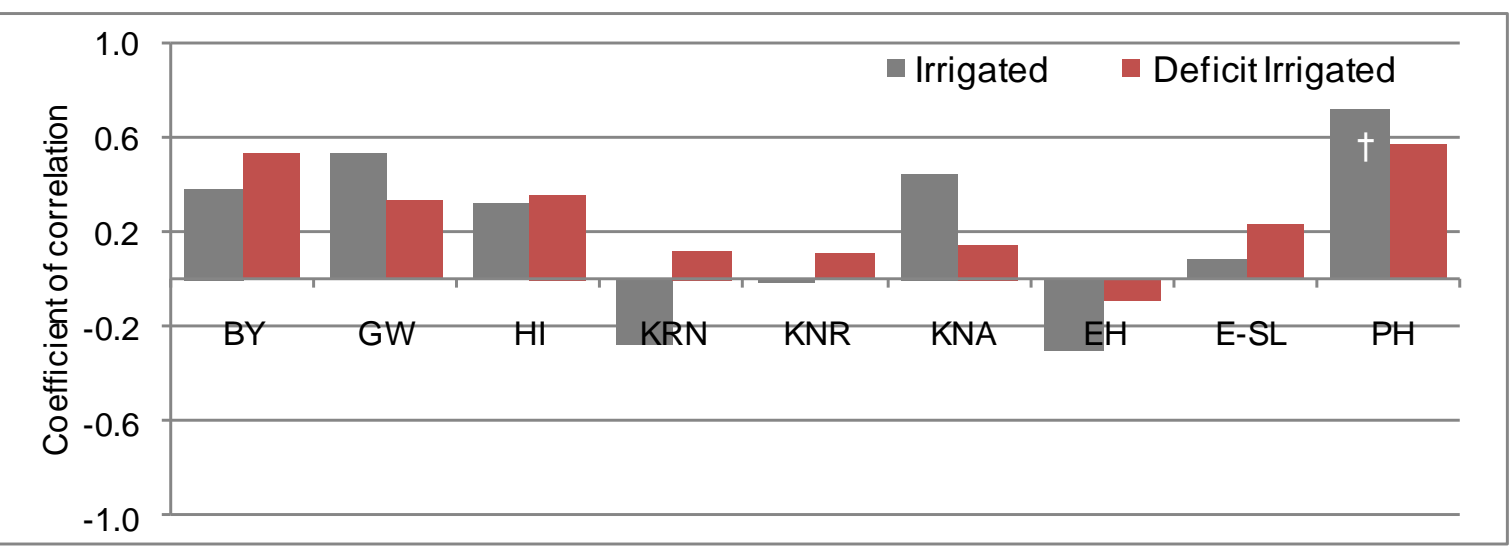

Figure 1 Pearson correlation coefficient between grain yield and agronomic traits of maize hybrids under irrigation regimes (Two years average). $\dagger$, significant $\mathrm{P}=0.057$ level; $\mathrm{PH}$, plant height; $\mathrm{E}-\mathrm{SL}$, ear-up stem length; $\mathrm{EH}$, ear height; KRN, kernel row number per-ear; KNR, kernel number per row; KNA, kernel number per area; GW, grain weight; HI, harvest index; GY, grain yield; BY, biomass yield.

The obtained results showed significant differences in kernel number per row among irrigation regime with compare to water stress that caused reductions in kernel number (-7.47\%) per row. In this study, a significant differences in harvest index between the irrigation regimes and the lowest values for harvest index $(50.5 \%)$ were obtained in water stress condition and the highest values $(53.2 \%)$ were recorded when crop grown under control condition (Table 2). Various investigations have been recorded that grain yield and yield attributes of maize were significantly influenced by irrigation regime treatments (Moser et al., 2006; Abd El-wahed et al., 2015; Barutcular et al., 2016; Rashwan et al., 2016). Further researcher reported that drought stress conditions decreased total productivity of maize due to reduction of kernel number per row and total kernel number per ear (Shoa Hoseini et al., 2007; Golbashy et al., 2010; ELSabagh et al., 2015). Further, yield losses were associated with the reduction in kernel number and kernel weight under deficiency of water at vegetative and reproductive phases of growth (Pandey et al. (2000).

3.2 Comparative evaluation of various hybrids of maize under irrigation regiemes

Significant differences with respect to grain yield and yield traits were observed among various genotypes, and highest reduction in yield was observed in hybrid variety 72 May80 and Sancia (Table 2). Grain yield is the result of the expression and association of several plant growths attributes. According to grain weight, the hybrids Indaco, 70May 82 and Aaccel were showed more positive effect of grain weight. Achieved results revealed that kernel number per area was significantly influenced by water stress conditions and that maximum value of kernel number per area was found in Calgary (5084 grains $\mathrm{m}^{-2}$ ) and minimum in 70May82 (4119 grains $\mathrm{m}^{-2}$ ). The obtained results in the same table revealed that maximum value of kernel rows per ear was found in 71 May69 (16.3 rows ear $\left.{ }^{-1}\right)$ and minimum rows in 70 May82 (13.3 rows $\left.^{-1}{ }^{-1}\right)$, while, the hybrid 70May82 produced higher values of kernel number per row (Table 2). In this experiment, the hybrid Aaccel was achieved the highest value of harvest index. The decrease in harvest index under water deficit stress showed the fact that both grain yield decreased under drought stress (Table 2). The varietal differences were found by other investigators include in which indicated actuality of high variety among hybrids studied for drought tolerance (Golbashy et al., 2010). Mostafavi et al. (2011) in a similar experiment observed that drought stress adversely influenced on the yield attributes and yield of maize hybrids. Perhaps, in addition to the reduction that happens in dry matter, water deficit disrupts the partitioning of carbohydrates to grains and hence, decreases harvest index. When maize plants were exposed to drought stress at tasseling stage, lead to substantial reduction in yield and yield components such a kernel number per row, kernel weight, kernels per cob, grain yield per plant, biological yield per plant and harvest index (Anjum et al., 2011; Abd ElWahed et al., 2015).

\subsection{Correlation analysis}

Correlation coefficients between the studied variables and total yield showed that only kernel row number and ear height were negatively correlated with grain yield under drought condition. While, the highest correlations were observed for grain yield and grain weight (Figure. 1). It was observed, under control conditions the kernel number per $\mathrm{m}^{2}$ was highly correlated with grain yield therefore, the hybrids with larger kernel number should be selected under irrigated condition to increase grain yield. Therefore, kernels per row and grain weight could be used as an important trait for prediction of grain yield under drought stress at the grain growth stage (Figure. 1). This finding is in agreement with the results of Shoa Hoseini et al. (2007) and Golbashy et al. (2010). 


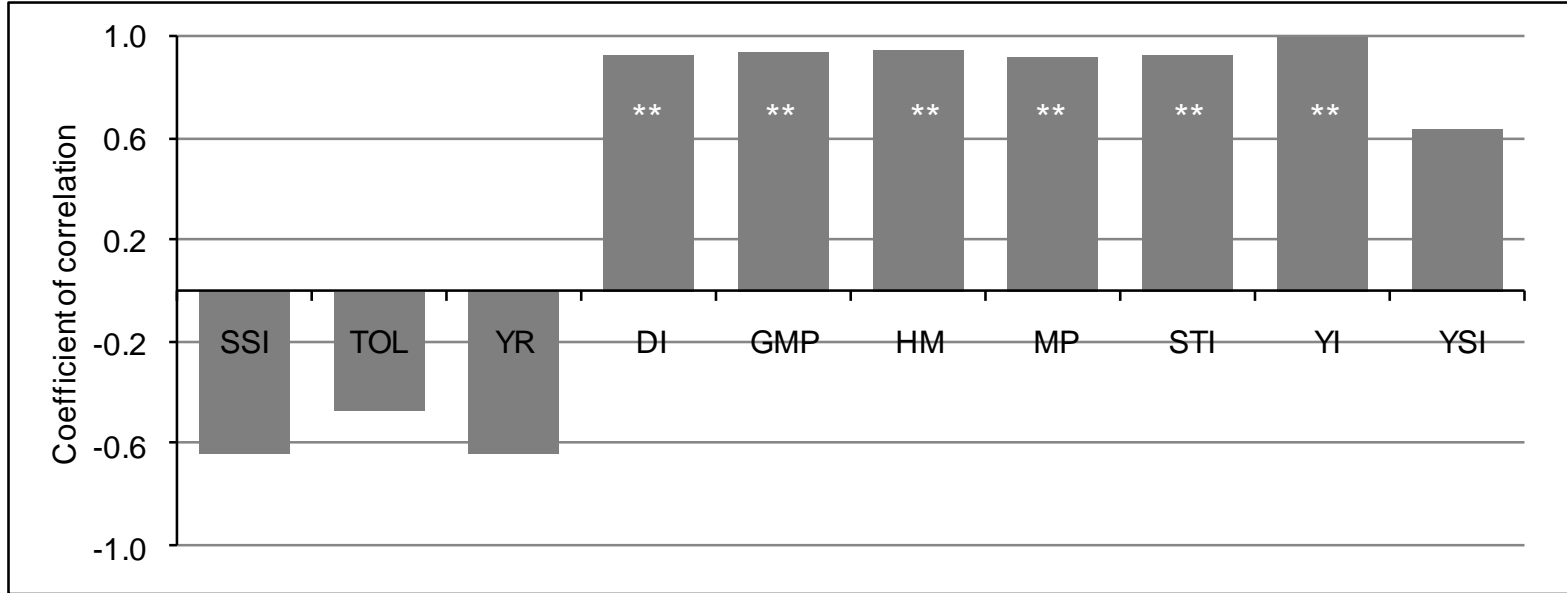

Figure 2 Pearson correlation coefficients between grain yield and drought indices(Two years average). **, significant P<0.01 level; SSI, stres susceptibility index; TOL, tolerance index; YR, yield reduction ratio; DI, drought resistance index; GMP, geometric mean productivity; HM, harmonic mean; MP, mean productivity; STI, stres tolerance index; YI, yield index; YSI, yield stability index.

3.4 Assessment, of maize hybrids by drought stress tolerant indices

For determining suitable stress tolerance indices to identify the hybrids for drought stress tolerance, grain yield of maize hybrids under stress conditions were calculated todetermine the various sensitivity and tolerance indices to provide the appropriate criterion for drought stress tolerant (Table 3 and Figure. 2). The high positive correlation was observed between grain yield and DRI, GMP, HM, MP, STI, YI and YSI and while, negative correlation was recorded between TOL, SSI and YR and grain yield in drought condition (Figure. 2). It was found that, genotypes, 70May82 and Indaco were recorded the high values of stress tolerance index (STI), geometric mean productivity (GMP) and mean productivity (MP), therefore, it could be identified astolerant hybrids to water stress conditions.Values of SSI lower than 1.0 denotes low drought susceptibility (or high yield stability) and values higher than 1.0 indicate high drought susceptibility (or poor yield stability). In the meantime the genotypes, 71May69, Aaccel and Calgary showed the lowest value in yield reduction ratio (YR) and therefore, would be more tolerant to water stress and could were identified as drought resistant genotypes. Finally, the genotypes with high values of yield stability index (YSI), drought resistance index (DI) and harmonic mean (HM) can be selected as tolerant genotypes to water stress such as 71May69, Aaccel and Calgarywere identified as drought tolerant genotypes because, these genotypes had greater values for DI, YSI and HM (Table 3). The genotypes with low value DSI values are drought tolerance because they have lesser reduction in grain yield under stress condition (Fayaz \& Arzani, 2011). SSI value more than 1.0 indicated aboveaverage sensitivity to water stress conditions (Guttieri et al., 2001). Abdipour et al. (2008) reported that using MP, GMP, and STI for screening drought stress tolerant as the most suitable indices. Kargar et al. (2004) identified GMP and STI as the best indices in separation superior genotypes in stress and nonstress condition. Kharrazi \& Rad (2011) reported that MP and STI indices are benefits to classified the tolerant genotypes.

Table 3 Calculated stress indices based on grain yield of maize hybrids.(Two years average).

\begin{tabular}{|c|c|c|c|c|c|c|c|c|c|c|}
\hline Hybrids & SSI $^{(\hat{\dagger})}$ & TOL $^{(\$)}$ & $\mathbf{Y} \mathbf{R}^{(\dagger)}$ & $\mathbf{D I}^{(\S)}$ & $\mathbf{G M P}^{(\$)}$ & $\mathbf{H M}^{(\S)}$ & $\mathbf{M P}^{(\$)}$ & STI $^{(\S)}$ & $\mathbf{Y I}^{(\$)}$ & $\mathbf{Y S I}^{(\$)}$ \\
\hline H1 & 1.075 & 222 & 0.176 & 0.662 & 1143 & 1138 & 1149 & 1.075 & 222 & 0.176 \\
\hline $\mathrm{H} 2$ & 1.138 & 250 & 0.186 & 0.689 & 1212 & 1206 & 1219 & 1.138 & 250 & 0.186 \\
\hline H3 & 0.995 & 216 & 0.163 & 0.719 & 1212 & 1208 & 1217 & 0.995 & 216 & 0.163 \\
\hline H4 & 0.880 & 185 & 0.144 & 0.728 & 1188 & 1184 & 1191 & 0.880 & 185 & 0.144 \\
\hline H5 & 0.763 & 160 & 0.125 & 0.758 & 1197 & 1194 & 1199 & 0.763 & 160 & 0.125 \\
\hline H6 & 1.035 & 222 & 0.169 & 0.699 & 1193 & 1188 & 1198 & 1.035 & 222 & 0.169 \\
\hline H7 & 1.109 & 226 & 0.181 & 0.646 & 1127 & 1121 & 1132 & 1.109 & 226 & 0.181 \\
\hline
\end{tabular}

$(\dagger)$ and (\$), low and high index values showed more tolerant cultivars for each indices, respectively. (SSI) Stress suscptibility index; (TOL) Tolerance index; (YR)Yield reduction ratio; (DI) Drought Resistance Index; (GMP)Geometric Mean Productivity; (HM) Harmonic Mean; (MP) Mean Productivity; (STI) Stress tolerance index; (YI )Yield Index; (YSI) Yield Stability Index.H1,Sancia; H2, Indaco; H3, 71May69; H4,Aaccel; H5, Calgari; H6, 70May82 and H7, 72May80. 


\section{Conclusions}

In the light of above results, water stress during grain filling stage can lead to loss in grain yield and causing a reduction of the productivity with compared to the full-irrigation condition of maize hybrids. there were high variation among hybrids, which could be befits for identifying drought-tolerant genotypes, and the hybrids 71May69, Aaccel and Calgary were more stable and appeared to more tolerant to drought stress with respect to grain yield loss, and Accordingly, the genotypes had high stress susceptibility index (SSI) and tolerance index (TOL), thus they were susceptible to drought and only suitable for irrigated conditions. Furthermore, GMP, MP, YI, STI, SSI and TOL were appropriate indices to identify maize hybrid tolerant to drought stress conditions. The results from this study, drought indices are very useful for planning future maize breeding programs especially, terminal drought stressin Mediterranean conditions.

\section{Conflict of interest}

Authors would hereby like to declare that there is no conflict ofinterests that could possibly arise.

\section{References}

Abdipour M, Rezaei AAH, Houshmand SA, Bagherifard G (2008) Evaluation of drought tolerance of indeterminate soybean genotypes in flowering and seed filling stages. Journal of Research in Agricultural Science 4: 140-150.

Abd El-Wahed MH, ELSabagh A, Zayed A, Sanussi A, Saneoka H, Barutcular C (2015) Improving yield and water productivity of maize grown under deficit-irrigated in dry areaconditions. Azarian Journal of Agriculture 2 : 123-132.

Anjum SA, Wang LC, Farooq M, Hussain M, Xue LL, Zou CM (2011) Brassinolide application improves the drought tolerance in maize through modulation of enzymatic antioxidants and leaf gas exchange. Journal Agronomy and Crop Science 197: 177-185. doi: http://dx.doi.org/10.1111/j.1439-037X.2010.00459.x

Barutcular C, Yıldırım M, Koç M, Akıncı C, Toptaş I, Albayrak O, Tanrıkulu A, EL Sabagh A (2016) Evaluation of SPAD chlorophyll in spring wheat genotypes under different environments. Fresenius Environmental Bulletin 25:12581266.

Bidinger FR, Mahalakshmi B, Rao GDP (1987) Assessment of drought resistance in breeding drought resistant winter wheat. Crop Science 28: 512-516.

Blum A (1996) Crop responses to drought and the interpretation to adaptation. Plant Growth Regulation 20: 135148. Doi: $10.1007 / B F 00024010$
Bouslama M, Schapaugh WT (1984) Stress tolerance in soybean. Part 1: evaluation of three screening techniques for heat and drought tolerance. Crop Science 24: 933-937. doi:10.2135/cropsci1984.0011183X002400050026x

Chen P, Haboudane D, Tremblay N, Wang J, Vigneault P, Li B (2010) New spectral indicator assessing the efficiency of crop nitrogen treatment in corn and wheat. Remote Sensing of Environment 114: 1987-1997. Doi: http://dx.doi.org/10.1016/j.rse.2010.04.006

EL Sabagh A, Barutçular C, Saneoka H (2015) Assessment of drought tolerance maize hybridsat grain growth stage in Mediterranean area. International Journal of Biological, Biomolecular, Agricultural, Food and Biotechnological Engineering 9 : 962-965.

FAO (2013) Food and Agriculture Organization of the United Nations. Available on http://faostat3.fao.org/download/Q/QC/E. accessed on 05 July 2016.

Farooq M, Wahid A, Kobayashi N, Fujita D, Basra SMA (2009) Plant drought stress: effects, mechanisms and management. Agronomy for Sustainable Development 29: 153-188. doi: http://dx.doi.org/10.1051/agro:2008021

Fatemi B, Kahraryan AG, Valizadeh M (2006) The evalustion of different irrigation regims and water requirement on yield and yield components of corn. The Journal of Agricultural Science 12: 133-141.

Fayaz N, Arzani A (2011) Moisture stress tolerance in reproductive growth stages in triticale (X Triticosecale Wittmack) cultivars under field conditions. Crop Breeding Journal 1: 1-12.

Fernandez GCJ (1992) Effective selection criteria for assessing plant stress tolerance. In: Kuo CG (Ed), Proceedings of the International Symposium on Adaptation of Vegetables and other Food Crops in Temperature and Water Stress, 13-18 August 1992, Tainan, Taiwan. p. 257-270.

Fischer RA, Maurer R (1978) Drought resistance in spring wheat cultivars.I. Grain yield responses. Australian Journal of Agriculture Research 29, 897-912.

Gavuzzi P, Rizza F, Palumbo M, Campaline RG, Ricciardi GL, Borghi B (1997) Evaluation of field and laboratory predictors of drought and heat tolerance in winter cereals. Plant Science 77: 523-531.

Golabadi MA, Arzani SA, Maibody M (2006) Assessment of drought tolerance in segregating populations in durum wheat. African Journal of Agricultural Research 1: 62-171.

Golbashy M, Ebrahimi M, Khavari Khorasani S, Choucan R (2010) Evaluation of drought tolerance of some corn (Zea 
mays L.) hybrids in Iran. African Journal of Agricultural Research 5 : 2714-2719.

Gomez KA, Gomez AA (1984) Statistical Procedures for Agricultural Research. John Wiley and Sons. New York. Pp. 680 .

Guttieri MJ, Stark JC, O’Brien K, SouzaE (2001) Relative sensitivity of spring wheat grain yield and quality parameters to moisture deficit. Crop Science 41 : 327-335. doi:10.2135/cropsci2001.412327x

Islam MS, Akhter MM, El Sabagh A, Liu LY, Nguyen NT, Ueda A, Masaoka Y, Saneoka H (2011) Comparative studies on growth and physiological responses to saline and alkaline stresses of Foxtail millet (Setaria italica L.) and Proso millet (Panicum miliaceum L.). Australian Journal of Crop Science 5 : 1269-77.

Kargar SMA, Ghannadha MR, Bozorgi-Pour R, Babaei H (2004). An investigation of drought tolerance indices in some soybean genotypes under restricted irrigation conditions. Iraninan Journal of Agricultural Science 35 : 129-142.

Kharrazi MAS, Rad MRN (2011). Evaluation of sorghum genotypes (Sorghum bicolor L. Moench) under drought stress conditions using some stress tolerance indices. African Journal of Biotechnology 10:13086-13089.

Khodarahmpour Z, Hamidi J (2012) Study of yield and yield components of corn (Zea mays L.) inbred lines to drought stress. African Journal of Biotechnology 11 : 3099-3105. doi.10.5897/AJB11.2974

Köksal ES (2011) Hyperspectral reflectance data processing through cluster and principal component analysis for estimating irrigation and yield related indicators. Agricultural Water Management 98: 1317-1328. doi.10.1016/j.agwat.2011.03.014

Menezes CB, Ticona-Benavente CA, Tardin FD, Cardoso MJ, Bastos EA, Nogueira DW, Portugal AF, Santos CV, Schaffert RE (2014) Selection indices to identify drought-tolerant grain sorghum cultivars. Genetics and Molecular Research 13 : 9817-9827.

DOI

http://dx.doi.org/10.4238/2014.November.27.9.

Mitra J (2001) Genetics and genetic improvement of drought resistance in crop plants. Current Science 80 : 758-762.

Mohammadi R, Amri A,Nachit M (2011) Evaluation and characterization of international Durum wheat nurseries under rainfed conditions in Iran. International Journal of Plant Breeding 5 : 94-100.
Moradi H, Akbari GA, Kvahari Khorasani S, Ramshini HA (2012) Evaluation of drought tolerance in corn (Zea mays L.) new hybrids with using stress tolerance indices. European Journal Sustainable Development 1: 543-560. doi: http://dx.doi.org/10.14207/ejsd.2012.v1i3p543

Moser SB, Feil B, Jampatong S, Stamp P (2006) Effect of preanthesis drought nitrogen fertilizer rate and variety on grain yield, yield components and harvest index of tropical maize. Agricultural Water Management 81: 41-58. doi: http://dx.doi.org/10.1016/j.agwat.2005.04.005

Mostafavi K, Geive HS, Dadresan M, Zarabi M (2011) Effects of drought stress on germination indices of corn hybrids (Zea mays L.). International Journal of Agricultral Science 1 : 1018.

Pandey RK, Maranville JW, Admou A (2000) Deficit irrigation and nitrogen effects on maize in a Sahelian environment: Grain yield and yield components. Agricultural Water Management 46: 1-13.doi: http://dx.doi.org/10.1016/S0378-3774(00)00073-1

Rashwan E, Mousa A, EL Sabagh A, Barutçular C (2016) Yield and Quality Traits of Some Flax Cultivars as Influenced by Different Irrigation Intervals. Journal of Agricultural Science $\quad 8 \quad$ 226-240.DOI: http://dx.doi.org/10.5539/jas.v8n10p226.

Reynolds MP, Rebetzke G, Pellegrinesci A, Trethowan R (2006) Drought adaptation in wheat. In: Ribaut JM (Ed.) Drought tolerance in cereals. Haworth Food \& Agricultural Products Press, New York. p. 402-436.

Rosielle AA, Hamblin J (1981) Theoretical aspects of selection for yield in stress and non-stress environments. Crop Science 21 doi: 10.2135/cropsci1981.0011183X002100060033x.

Roth JA, Ciampitti IA, Vyn TJ (2013) Physiological Evaluations of Recent Drought-Tolerant Maize Hybrids at Varying Stress Levels. Agronomy Journal 105:1129-1141.

Shoa Hoseini M, Farsi M, Khavari khorasani S (2007) Study effect of water deficit stress on yield and yield components if some corn hybrids using path analysis. Majale Danesh Keshavarzi,18, 71-85.

Sio-Se Mardeh A, Ahmadi A, Poustini K, MohammadiV(2006) Evaluation of drought resistance indices under various environmental conditions. Field Crops Research 98: 222-229.doi: http://dx.doi.org/10.1016/j.fcr.2006.02.001. 